\title{
Cytotoxic T Lymphocyte Response to Hepatitis C Virus-derived Peptides Containing the HLA A2.1 Binding Motif
}

\author{
Andreas Cerny, ${ }^{\star s}$ John G. McHutchison, * Claudio Pasquinelli, * Michael E. Brown, * Mary A. Brothers, * \\ Benno Grabscheid, ${ }^{\$}$ Patricia Fowler, ${ }^{\star}$ Michael Houghton, ${ }^{\star}$ and Francis V. Chisari ${ }^{*}$ \\ ${ }^{*}$ The Scripps Research Institute, La Jolla, California 92037; ${ }^{\ddagger}$ Chiron Corporation, Emeryville, California 94608; and ${ }^{\S}$ University \\ Hospital, Inselspital, 3010 Bern, Switzerland
}

\begin{abstract}
The HLA class I-restricted cytotoxic T lymphocyte (CTL) response is a major defense mechanism in viral infections. It has been suggested that the CTL response may contribute to viral clearance and liver cell injury during hepatitis $\mathrm{C}$ virus (HCV) infection. To test this hypothesis requires an understanding of the characteristics of $\mathrm{HCV}$-specific cytotoxic effector cells and identification of the target antigens to which they respond. To begin this process we stimulated peripheral blood mononuclear cells (PBMC) from a group of HLA-A2 positive patients with chronic hepatitis $C$ with a panel of $130 \mathrm{HCV}$-derived peptides containing the HLAA2 binding motif. Effector cells were tested for their capacity to lyse HLA-A2-matched target cells that were either sensitized with peptide or infected with a vaccinia virus construct containing HCV sequences. Using this approach we have identified nine immunogenic peptides in $\mathrm{HCV}$, three of which are derived from the putative core protein, three from the nonstructural (NS) 3 domain, two from NS4 and one from NS5. Selected responses were shown to be HLAA2 restricted, mediated by $\mathrm{CDB}^{+} \mathrm{T}$ cells and to recognize endogenously synthesized viral antigen. Unexpectedly, peptide-specific CTL responses could also be induced in seronegative individuals, suggesting in vitro activation of naive CTL precursors. The precursor frequency of peptide-specific CTL was 10 to 100 -fold higher in infected patients compared to uninfected controls, and the responses were greatly diminished by removal of $\mathrm{CD}^{2} 5 \mathrm{RO}^{+}$(memory) $\mathrm{T}$ cells. Further quantitative studies are clearly required to establish whether a correlation exists between the HCV. specific CTL response and the clinical course of this disease. Definition of the molecular targets of the human CTL response to HCV creates this opportunity, and may also contribute to the development of a $T$ cell-based $H C V$ vaccine. (J. Clin. Invest. 1995. 95:521-530.) Key words: hepatitis C virus $\cdot$ cytotoxic $T$ lymphocytes $\cdot T$ cell epitope $\cdot$ HLA-A2 $\cdot \mathrm{HBV} \cdot \mathrm{HCV}$
\end{abstract}

This work was presented in part at the Keystone Symposium: Molecular Immunology of Virus Infections held in Taos, New Mexico, March 17

24, 1993 and at the International Symposium on Viral Hepatitis and Liver Disease held in Tokyo, May 10-14, 1993.

Address correspondence to Dr. Francis V. Chisari, The Scripps Research Institute, Department of Molecular \& Experimental Medicine, 10666 North Torrey Pines Road, La Jolla, CA 92037. Phone: 619-5548228; FAX: 619-554-6134.

Received for publication 25 August 1993 and in revised form 23 September 1994.

J. Clin. Invest.

(C) The American Society for Clinical Investigation, Inc.

0021-9738/95/02/521/10 \$2.00

Volume 95, February 1995, 521-530

\section{Introduction}

The hepatitis $\mathrm{C}$ virus $(\mathrm{HCV})^{1}$ is the major cause of non-A, non-B viral hepatitis $(1,2,3)$. The most striking feature of $\mathrm{HCV}$ induced liver disease is its tendency towards chronicity and slowly progressive liver cell injury. The mechanisms responsible for tissue injury in acute and chronic HCV infection are not well understood and it is possible that both direct, virus related, or indirect, i.e., immunologically mediated, mechanisms may be involved.

While the $\mathrm{CD}^{+}{ }^{+} \mathrm{T}$ cell response certainly plays a role in viral resistance and immunopathology, its involvement at the effector cell level is unclear since it is targeted primarily at internalized extracellular antigens in the context of HLA class II molecules, and because multiple, often antagonistic, functions have been attributed to the different subsets of $\mathrm{CD}^{+}{ }^{+} \mathrm{T}$ helper cells (4). HLA class I-restricted cytotoxic $T$ lymphocytes (CTL), on the other hand, are widely acknowledged as a major effector mechanism in viral infections. CTL-mediated lysis of virus infected cells is thought to lead to clearance of the virus or, if incomplete, to viral persistence and chronic tissue injury (5). Virus-specific CTL have been demonstrated in the peripheral blood $(6,7,8)$ and in the liver (9) during acute viral hepatitis caused by the hepatitis B virus (HBV). Based on these observations, and on parallels with other viral diseases, immunologically mediated liver cell injury is thought to be responsible for chronic hepatitis after infection with HCV (10). The recent demonstration of HCV-specific CTL in the intrahepatic inflammatory infiltrates of patients with chronic hepatitis $\mathrm{C}$ provide further support for this concept (11).

$\mathrm{CD}^{+} \mathrm{CTL}$ interact through their polymorphic $\mathrm{T}$ cell receptors with HLA class I molecules containing endogenously synthesized peptides of 8 to 11 residues (usually 9 or 10) on the surface of infected cells (12). The peptide binding motifs of many common HLA class I alleles such as A2.1, Aw68, B7, B27, and HLA-C have been published (13-17). Because of the high frequency of the HLA A2.1 allele in most populations (Caucasians: $46 \%$; Japanese: 43\%; Chinese: 55\%; Africans: $27 \%$ ), we have used HBV derived synthetic peptides containing the HLA-A2.1 binding motif to identify and characterize the HLA-A2-restricted CTL response in the peripheral blood during acute HBV infection $(6-8,18,19)$. We now report the successful use of this approach for the detection of HCV-specific CTL in the peripheral blood of patients with chronic HCV infection, and also (in lower numbers) in seronegative controls.

\section{Methods}

Patient population. All patients and normal subjects included in this study were HLA-A2 positive. The diagnosis of $\mathrm{HCV}$ infection was

1. Abbreviations used in this paper: CTL, cytotoxic T lymphocyte; $\mathrm{HBV}$, hepatitis $B$ virus; $\mathrm{HCV}$, hepatitis $\mathrm{C}$ virus. 
Table I. Characteristics of HCV-Positive Patients

\begin{tabular}{llrll}
\hline $\begin{array}{c}\text { Subject } \\
\text { (sex) }\end{array}$ & \multicolumn{1}{c}{ HLA } & ALT & $\begin{array}{l}\text { HCV- } \\
\text { PCR* }^{*}\end{array}$ & Liver biopsy \\
\hline C-1(m) & A2,B44,Cw3 & 226 & pos. & CAH + C \\
C-2(f) & A2,A31,B7,B67,Cw7 & 99 & pos. & CAH \\
C-3(m) & A2,A3,B44,Cw7 & 155 & pos. & CAH \\
C-4(m) & A2,A30,Bw48,Bw64,Cw3 & 79 & pos. & CAH \\
C-5(f) & A2,A3,B65,B75,Cw1,Cw4 & 97 & pos. & CAH \\
C-6(f) & A2,A24,B38,B60,Cw3 & 190 & pos. & CAH \\
C-7(m) & A2,A24,B7,Bw62,Cw3 & 113 & pos. & CAH \\
C-8(f) & A2,A24,B18,B67,Cw7 & 37 & nd & CAH \\
C-9(m) & A2,A3,B67,B35,Cw4 & 244 & nd & CAH \\
C-10(m) & A2,A24,B38,B50,C? & 190 & nd & CAH \\
H-1(m) & A2,A1,B8,B44,Cw5,Cw7 & nl & pos. & nd" \\
H-2(f) & A2,A68,B7 801,Cw6 & nl & pos. & nd \\
& & & & \\
\hline
\end{tabular}

* The diagnosis of HCV infection was based on standard serological assays using the second-generation (c200/c22-3) Ortho HCV ELISA test system (Ortho Diagnostics, Inc., Raritan, NJ). HCV RNA was detected using a nested cDNA polymerase chain reaction assay with primers selected from the $5^{\prime}$ noncoding region and subsequent hybridization using an internal probe. ${ }^{\ddagger} \mathrm{CAH}=$ biopsy proven chronic active hepatitis (CAH) with or without cirrhosis (C). " This subject was convalescent from hepatitis B infection (HBsAg negative, anti-HBs positive, anti$\mathrm{HBc}$ positive, anti-HBe positive). "This subject had no history of hepatitis and had normal liver enzymes, no biopsy was performed. 'This subject had an episode of acute hepatitis $\mathrm{C}$ three months previously, no biopsy was performed.

based on standard clinical parameters and serological assays using the second-generation (c200/c22-3) Ortho HCV ELISA test system (Ortho Diagnostics, Inc., Raritan, NJ). 10 patients had biopsy proven chronic hepatitis (C-1 to C-10) and two patients had anti-HCV antibodies without signs of liver disease ( $\mathrm{H}-1$ and $\mathrm{H}-2)$. One of these patients (C-3) also had a clinical history and serological evidence of acute HBV infection 3 mo before his entry into this study. The pertinent serological and clinical parameters defining this group of patients are listed in Table I. Additionally, six healthy subjects without clinical or serological evidence of $\mathrm{HBV}$ or $\mathrm{HCV}$ infection, designated $\mathrm{N}-1$ (m, A2, A1, B8, B18, Cw7), N-2 (f, A2, A1, B64, B35, Cw4, Cw7), N-3 (m, A2, B44, Cw7), N-4 (m, A2, A32, B18, B60, Cw3, Cw7), N-5 (f, A2, A3, B7, B60, Cw3, Cw7), N-6 (f, A2, A25, B18, B62, Cw3) served as controls. Four patients with chronic hepatitis $B$ defined by standard clinical and serological criteria, designated B-1 (m, A2, A1, B8, B8w58, Cw7), B2 ( $\mathrm{m}, \mathrm{A} 2, \mathrm{~A} 34, \mathrm{~B} 8, \mathrm{~B} 27, \mathrm{C} 7$ ), B-3 (m, A2, A30, B44, B1, C?), B-4 (m, $\mathrm{A} 2, \mathrm{Aw68}, \mathrm{Bw59}, \mathrm{B} 44, \mathrm{Cw} 5, \mathrm{Cw} 7)$ were also included for comparison. Concomitant infection with HIV was excluded serologically in all subjects studied.

Synthetic peptides. A panel of 53 synthetic peptides (9-10 mers) derived from the HCV-1 isolate (20) (Okamoto group I (21), Simmonds genotype 1a (22)) that contain the classical HLA-A2 binding motif (i.e., a leucine in the second position and a valine at the carboxy terminus) were selected for our initial studies. This panel contained two peptides from the core region, two from E1, 6 from E2/NS1, 9 from NS2, nine from NS3, 10 from NS4, and 15 from NS5. An additional 77 peptides (panel 2) that contain an extended HLA-A2 motif (leucine, methionine, isoleucine or valine in the second position and valine, leucine or isoleucine at the carboxy-terminus) and are conserved in $100 \%$ of the HCV-1a genotype (22) sequences in the GenBank database was subsequently studied. This panel contained 9 peptides from the core region, 4 from E1, 9 from E2/NS1, 18 from NS3, 12 from NS4, and 24 from NS5. Two peptides previously identified as CTL epitopes in patients with acute hepatitis B, HBV core 18-27 (FLPSDFFPSV) (6) and HBVenv335-343 (WLSLLVPFV) (8), were used as controls. All peptides were produced by Chiron Mimotopes (Clayton, Australia) and contained free amine $\mathrm{N}$-termini and free acid $\mathrm{C}$-termini. Lyophilized peptides were reconstituted at $20 \mathrm{mg} / \mathrm{ml}$ in DMSO (Malinckrodt, Paris, $\mathrm{KY}$ ) and diluted to $1 \mathrm{mg} / \mathrm{ml}$ with RPMI 1640 medium (GIBCO BRL, Grand Island, NY).

PCR analyses of patient samples. HCV RNA was detected in sera using a nested cDNA polymerase chain reaction assay with primers selected from the $5^{\prime}$ untranslated region and subsequent hybridization using an internal probe as previously described (23). All seronegative controls ( $\mathrm{N}-1$ through $\mathrm{N}-6)$ as well as patients with chronic hepatitis $B$ infection (B-1 through B-4) had no detectable HCV RNA in the serum.

Stimulation of PBMC with synthetic peptides and tetanus toxoid. PBMC from donors were separated on Ficoll-Hypaque density gradients (Sigma Chemical Co., St. Louis, MO), washed three times in Hanks balanced salt solution (HBSS) (GIBCO BRL) resuspended in RPMI 1640 medium (GIBCO BRL) supplemented with L-glutamine ( $2 \mathrm{mM})$, gentamicin $(10 \mu \mathrm{g} / \mathrm{ml})$, penicillin $(50 \mathrm{U} / \mathrm{ml})$, streptomycin $(50 \mu \mathrm{g} /$ $\mathrm{ml}$ ), and Hepes $(5 \mathrm{mM})$ containing $10 \%$ heat-inactivated human $A B$ serum (complete medium) and plated in 24-well plates at $4 \times 10^{6}$ cells/well. PBMC from patients $\mathrm{C}-1$ through $\mathrm{C}-7, \mathrm{H}-1$ and $\mathrm{H}-2$ were stimulated individually with the synthetic peptides from panel 1 at a final concentration of $10 \mu \mathrm{g} / \mathrm{ml}$. PBMC from patients C-8 and C-9 were stimulated with pools of peptides from panel 2 containing four peptides per pool at a final concentration of $2.5 \mu \mathrm{g} / \mathrm{ml}$ per peptide. PBMC from patients C-3, C-7, C-10, B1-4, and N1-4 were stimulated with selected individual HCV and HBV peptides as described above. In all cases, tetanus toxoid (Connaught Laboratories, Swiftwater, PA) was added at $1 \mu \mathrm{g} / \mathrm{ml}$ during the first week of stimulation. On day $3,1 \mathrm{ml}$ of complete medium supplemented with rIL2 (Hoffman-La Roche, Nutley, NJ) at $10 \mathrm{U} / \mathrm{ml}$ final concentration was added in each well. On day 7, the cultures were restimulated with the original peptide (or peptide pool) plus rIL2 and irradiated (3,000 rads) autologous feeder cells, and the cultured PBMC were tested for CTL activity against the stimulating peptide (or pool) on day 14. Selected cultures that displayed peptidespecific cytolytic activity after 2 wk of stimulation were expanded by weekly restimulation with $1 \times 10^{6}$ irradiated $(3,000$ rads $)$ autologous PBMC in $1 \mathrm{ml}$ of complete medium containing $10 \mu \mathrm{g} / \mathrm{ml}$ peptide and $20 \mathrm{U} / \mathrm{ml} \mathrm{IL2}$, and tested against the stimulating peptide, or constituent peptides (in the case of peptide pools) and against target cells infected with recombinant HCV-vaccinia viruses (see below).

Cell separation. CD4- and CD8-positive $\mathrm{T}$ cells were purified by panning using positive selection with anti-CD4 or anti-CD8 antibodies and depletion of CD45 RO positive cells was done using negative selection according the manufacturers instructions (AIS MicroCellector Applied Immune Sciences, Inc. Menlo Park, CA) with the UCHL1 monoclonal antibody (Biodesign, Kennebunkport, ME).

Generation of HCV-specific CTL clones. CTL lines were cloned at $0.3,1,10$, and 100 cells per well and then subcloned at 0.3 or 1 cell per well in 96-well microtiter plates. The cells were plated in the presence of peptide $(1 \mu \mathrm{g} / \mathrm{ml})$, PHA $(1 \mu \mathrm{g} / \mathrm{ml}), \mathrm{rIL}-2(20 \mathrm{U} / \mathrm{ml})$, irradiated $(3,000$ rads) allogeneic PBMC $\left(10^{5}\right.$ cells/well $)$. HCV-specific CTL clones were expanded by restimulation in a 24-well plate as described above.

Target cells. Allogeneic and autologous EBV-transformed B lymphoblastoid cell lines (B-LCL) were either purchased from The American Society for Histocompatibility and Immunogenetics (Boston, MA) or established from our own pool of patients and normal donors. The most commonly used target cell line (JY) is HLA-A2, B7 and Cw7 positive. The cells were maintained in RPMI 1640 supplemented with L-glutamine $(2 \mathrm{mM})$, gentamicin $(10 \mu \mathrm{g} / \mathrm{ml})$, penicillin $(50 \mathrm{U} / \mathrm{ml})$, streptomycin $(50 \mu \mathrm{g} / \mathrm{ml})$, Hepes $(5 \mathrm{mM})$, and $10 \%$ ( $\mathrm{vol} / \mathrm{vol})$ heat inactivated FCS (GIBCO BRL).

Recombinant expression vectors. Recombinant vaccinia viruses that express HCV-1 core/E1 (aa 1-339) and E2/NS2/NS3 (aa 364-1619) were generated according to standard procedures as previously described (24) and shown to express the appropriate HCV proteins by radioimmunoprecipitation (25) (and Q.-L. Choo and M. Houghton, unpublished data). A vaccinia virus expressing only the E.coli $\beta$-galactosidase gene was used as a control (26). Vaccinia infected targets were prepared by infection of $1 \times 10^{6}$ cells at a multiplicity of infection (MOI) of 10:1 
to $100: 1$ on a rocking platform at room temperature for one hour followed by a single wash and overnight incubation at $37^{\circ} \mathrm{C}$.

Cytotoxicity assay. Target cells consisted of allogeneic HLAmatched and mismatched B-LCL incubated overnight with synthetic peptides at $10 \mu \mathrm{g} / \mathrm{ml}$. Target cells were labeled with $100 \mu \mathrm{Ci}$ of ${ }^{51} \mathrm{Cr}$ (Amersham Corp., Arlington Heights, IL) for $1 \mathrm{~h}$ and washed three times with HBSS. Cytolytic activity was determined in a standard 4-h ${ }^{51} \mathrm{Cr}$-release assay using U-bottom 96-well plates containing 5,000 targets per well. All assays were performed in duplicate. Percent cytotoxicity was determined from the formula: $100 \times[$ [experimental release - spontaneous release)/(maximum release - spontaneous release)]. Maximum release was determined by lysis of targets with detergent (1\% Triton X-100; Sigma Chemical Co.). Spontaneous release was $<25 \%$ of maximal release in all assays. A difference in the specific lysis of peptide pulsed target cells and nonpulsed target cells of $15 \%$ at an effector to target cells ratio between 40 and 80:1 in the initial CTL assay performed after 2 wk of culture was arbitrarily considered to represent a positive CTL response, and was confirmed by retesting after additional rounds of restimulation and subsequent cloning. The peptide-specific cytotoxicity observed against the HCV derived peptides that were not found to be CTL epitopes was typically below 5\% (range $0-12 \%)$.

Limiting dilution analysis. Three or four different responder cell concentrations were set up in 24 replica cultures in complete medium and peptide ( $10 \mu \mathrm{g} / \mathrm{ml}$ ) complemented with graded numbers of autologous irradiated PBMC (3,000 rads) to give a total cell number of 1 $\times 10^{6}(1 \mathrm{ml}$ cultures in 48 -well plates $)$ or $0.2 \times 10^{6}(0.2 \mathrm{ml}$ cultures in 96-well plates). A fixed number of $0.1 \times 10^{6}$ autologous irradiated PBMC was used for the CD45RO-depletion experiments $(0.2 \mathrm{ml}$ cultures in 96-well plates) to prevent the introduction of an experimental bias due to removal of CD45 $\mathrm{RO}^{+}$antigen presenting cells. On days 3 and $10 \mathrm{rIL} 2$ at $10 \mathrm{U} / \mathrm{ml}$ final concentration was added in each well. On day 7 and 14, the cultures were restimulated with the original peptide plus rIL2 and irradiated (3,000 rads) autologous feeder cells $\left(1 \times 10^{6} /\right.$ $\mathrm{ml}$ ) and on day 21 the individual cultures were split and tested for CTL activity against JY target cells sensitized with the stimulating peptide or with medium alone. The cutoff point to define a positive response was calculated as the mean $\pm 2 \mathrm{SD}$ of peptide-specific killing of negative wells. The test was initially developed for the quantitation of influenza virus matrix peptide M58-68 (27) (Cerny et al. manuscript in preparation). The CTL precursor frequencies estimates and confidence intervals were calculated using the ELIDA software by Carl Taswell (28).

Flow cytometry. Cells to be analyzed $\left(0.5 \times 10^{6}\right)$ were washed once in PBS and then incubated with fluorescent probe-conjugated antiCD4 and anti-CD8 monoclonal antibodies (Leu3a, Leu2a) and similarly labeled control antibody (Becton Dickinson). After a 30-min incubation at $4^{\circ} \mathrm{C}$, cells were washed in PBS with 5\% BSA and analyzed with a FACScan ${ }^{\star}$ flow cytometer (Becton Dickinson). Removal of CD45 RO positive cells was checked using anti CD45 RO monoclonal antibodies (UCLH1) as a first step and a fluorescein labelled goat anti-mouse IgG antibody as second step.

HLA typing. HLA typing of PBMC from patients and from normal donors was determined by microcytotoxicity, using HLA typing trays (One Lambda, Canoga Park, CA). The HLA haplotypes of patients participating in this study are shown in Table I.

\section{Results}

Screening of $H C V$ peptide-specific responses. In this experiment (Fig. 1) PBMC from eight HLA-A2 positive HCV infected subjects were stimulated individually with the 53 peptides from HCV panel 1, and cultures were tested after 2 wk of initial expansion for peptide-specific CTL activity. Peptidespecific cytotoxic $T$ cell activity was observed against seven of the peptides (Table II). Three of the subjects studied (3/6 with $\mathrm{CAH})$ responded to at least one of the peptides. Subject C-2 responded to five peptides, two of which are derived from $\mathrm{HCV}$ core, one from NS3, NS4 and NS5 respectively. Subject C-3

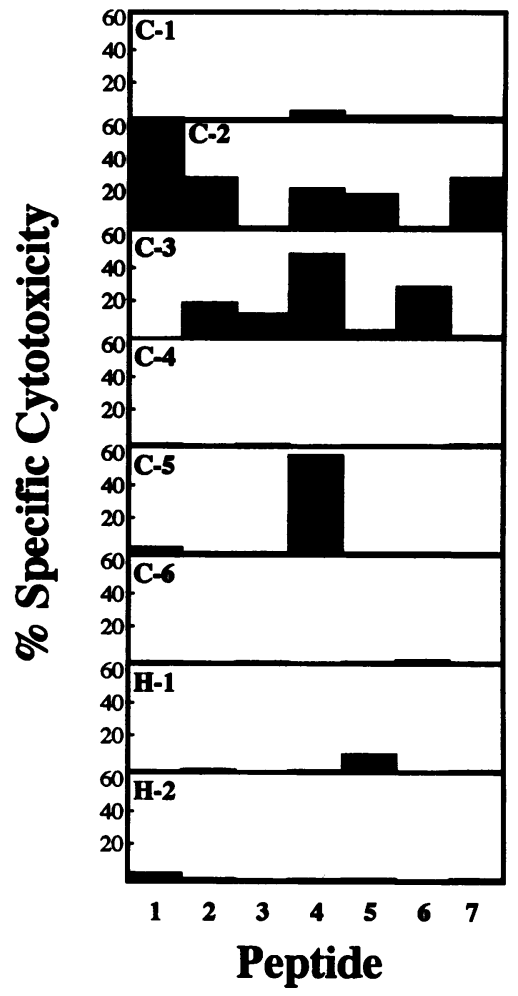

Figure 1. PBMC from eight HCV-positive patients were stimulated individually with each member of a panel of 53 HCV-derived peptides containing the HLAA2.1 binding motif. After 2 wk of stimulation, HCV-specific CTL responses to 7 of these peptides were observed in 3 of the patients. The peptide specific cytotoxicity observed with the other 46 HCV-derived peptides was $<15 \%$ (range $0-12 \%$ ) and it was typically below $5 \%$ (not shown). PBMC from subjects C-1 to C-6 (subjects with $\mathrm{HCV}$ associated liver disease), and $\mathrm{H}-1$ and $\mathrm{H}-2$

(healthy but positive for antibody to $\mathrm{HCV}$ ) were expanded using the following HCV-derived synthetic peptides: 1 core 131-140; 2-core 178-187; 3-NS3 1169-1177; 4-NS3 1406-1415; 5-NS4 1789-1797; 6-NS4 1807-1816; 7-NS5 2252-2260. The peptide specific cytotoxicity after $2 \mathrm{wk}$ of culture at an effector to target cell ratio ranging from 40-80:1 is shown. HLAA2 matched JY EBV-BCL served as target cells. Percent specific lysis represents the difference between the CTL-induced ${ }^{51} \mathrm{Cr}$ release from JY cells that had been previously pulsed with the corresponding peptide and JY cells that had been pulsed with media in the absence of peptide.

responded to three peptides, including HCV core 178-187 but not HCV core 131-140. Several of the peptides, especially NS3 1406-1415 were found to be stimulatory for more than one patient, possibly reflecting a higher degree of immunogenicity. It is notable that 46 of the 53 peptides were nonstimulatory to these patients and that five of the patients $(\mathrm{C}-1, \mathrm{C}-4, \mathrm{C}-6, \mathrm{H}-$ $1, \mathrm{H}-2$ ) did not respond to any of the peptides in the panel. Restimulation of cultures yielding a marginal CTL response at 2 wk revealed additional responses in subject C-5 to HCV core 131-140, C-3 to NS3 1169-1177 and H-1 to NS4 1789-1797.

To determine whether the in vitro expansion of CTL using synthetic peptides reflects previous in vivo exposure, we analyzed the responses of four HCV infected patients (C-3, C-7, C-10, H-2), four patients with chronic HBV infection (B-1 to B-4), and four normal seronegative control subjects ( $\mathrm{N}-1$ to $\mathrm{N}-$ 4) using four of the foregoing stimulatory HCV peptides and two known HBV epitopes (Fig. 2, Experiment I). Interestingly, we observed CTL responses to the HCV peptides in several HCV-uninfected subjects after 2 wks of stimulation, while a CTL response to the $\mathrm{HBV}$ peptides was seen only in patient C3 , who was recently convalescent from acute $\mathrm{HBV}$ infection, and patients B-2 and B-3, who were chronically infected by HBV. This was confirmed by another smaller experiment (Fig. 2, Experiment II) using $2 \mathrm{HCV}$ and one $\mathrm{HBV}$-peptide for the stimulation of PBMC derived from two patients with chronic hepatitis C (C-3, C-7), two with chronic hepatitis B (B-3, B$4)$, and two normal healthy controls (N-2, N-4). The observed 
Table II. HCV-1 Derived Peptides Recognized by CTL and Their Representation among Known HCV Sequences

\begin{tabular}{|c|c|c|c|c|c|c|c|}
\hline \multirow[b]{2}{*}{ HCV-region } & \multirow[b]{2}{*}{ aa Residues } & \multirow[b]{2}{*}{ Sequence } & \multicolumn{5}{|c|}{ HCV group* } \\
\hline & & & I & II & III & IV & ND \\
\hline Core & $35-44$ & YLLPRRGPRL & $3^{\ddagger} / 3^{8}$ & $6 / 8$ & $3 / 3$ & $2 / 2$ & $5 / 8$ \\
\hline Core & $131-140$ & ADLMGYIPLV" & $3 / 3$ & $8 / 8$ & $1 / 3$ & $2 / 2$ & $7 / 8$ \\
\hline Core & $178-187$ & LLALLSCLTV & $3 / 3$ & $1 / 11$ & $0 / 3$ & $2 / 2$ & $2 / 8$ \\
\hline NS3 & $1073-1081$ & CINGVCWTV & $3 / 3$ & $1 / 5$ & $0 / 1$ & $0 / 1$ & $1 / 1$ \\
\hline NS3 & $1169-1177$ & LLCPAGHAV & $2 / 3$ & $0 / 5$ & $0 / 1$ & $0 / 1$ & $0 / 1$ \\
\hline NS3 & $1406-1415$ & KLVALGINAV & $4 / 5$ & $0 / 5$ & $0 / 1$ & $0 / 1$ & $0 / 1$ \\
\hline NS4 & $1789-1797$ & SLMAFTAAV & $3 / 3$ & $0 / 5$ & $0 / 1$ & $0 / 1$ & $0 / 1$ \\
\hline NS4 & $1807-1816$ & LLFNILGGWV & $3 / 3$ & $5 / 5$ & $0 / 1$ & $0 / 1$ & $1 / 1$ \\
\hline NS5 & $2252-2260$ & ILDSFDPLV & $3 / 3$ & $0 / 5$ & $0 / 1$ & $0 / 1$ & $0 / 1$ \\
\hline
\end{tabular}

The single-letter code for amino acids is used: A, Ala; C, Cys; D, Asp; E, Glu; F, Phe; G, Gly; H, His; I, Ile; K, Lys; L, Leu; M, Met; N, Asp; P, Pro; Q, Gln; R, Arg; S, Ser; T, Thr; V, Val; W, Trp; Y, Tyr. * HCV groups as described by Okamoto et al. (21). ND, not determined. ${ }^{\ddagger}$ Number of sequences that show no amino acid substitutions within a given epitope. ${ }^{8}$ Total number of sequences deposited in GenEMBL covering a given epitope. "This peptide sequence was inadvertently produced instead of same sequence without alanine 131, which would more precisely correspond to the HLA A2.1 motif.

variability in some of the peptide-specific CTL responses in the three experiments shown in Figs. 1 and 2 could be due to the use of PBMC from different bleeding dates in the various experiments containing different numbers of CTL precursors, or to interassay variations. The finding that HCV peptide-specific CTL can be detected in the PBMC of uninfected subjects after 2 wk of peptide stimulation was surprising, and it raised the possibility that the responses we previously observed in the $\mathrm{HCV}$-infected patients might reflect in vitro priming by the peptides rather than in vivo priming by exposure to virus.

As an extension of the foregoing studies we tested the responsiveness of patients C3, C-8, and C-9 to 19 pools of 77 peptides from panel 2 (4-5 peptides per pool). These studies led to the identification of two additional CTL epitopes (Core 35-44 and NS3 1073-1081) for which CTL lines could be established, as shown in Table III (Experiment B). The HCV derived peptides recognized by CTL identified in this study as well as their conservation among sequences derived from various $\mathrm{HCV}$ isolates are summarized in Table II.

Characterization of $\mathrm{HCV}$ peptide-specific CTL lines and clones. To establish highly cytotoxic $\mathrm{T}$ cell lines for further study and generation of CTL clones, we restimulated the responsive cultures weekly with autologous irradiated PBMC, peptide and IL-2. Fig. 3 shows an example of typical CTL lines, obtained from patient C-3 after four weeks of peptide stimulation, that are specific for HCV core 178-187, NS3 1169-1177 and NS3 1406-1415, and lyse HLA A2-matched peptide-pulsed EBV-BCL in a dose-dependent fashion. For most of these lines we generally observed a progressive increase of cytolytic activity after each round of peptide stimulation (Table III). Interestingly, for the CTL response of subject C-2 to NS5 2252-2260 we observed $29 \%$ specific cytotoxic activity at an E/T of 84 / 1 after 2 wk of stimulation in one blood sample, although we could not detect any significant CTL activity after 2 or 3 wk of stimulation of PBMC collected two months later. Continuing restimulation of PBMC from the later date revealed peptidespecific CTL after 4 and $5 \mathrm{wk}$, however. While this may reflect fluctuation of the CTL precursor frequency in the course of $\mathrm{HCV}$ infection, it could also reflect the in vitro induction of peptide-specific CTL. This was addressed in an additional experiment (Table III, Experiment $C$ ) comparing NS3 1406-1415 stimulated cultures derived from $\mathrm{HCV}$ infected subject $\mathrm{C}-7$ and uninfected donor $\mathrm{N}-2$. Whereas CTL were readily detectable in patient C-7 after 2 wk of stimulation, 4 wk of repetitive stimulation were required before peptide-specific CTL became detectable in subject $\mathrm{N}-2$. As shown below, these differences correlate with a lower peptide-specific CTL precursor frequency in C-7 as compared to $\mathrm{N}-2$ (Fig. $6 \mathrm{~B}$ )

$H L A$ restriction analysis. HLA class I restriction analysis of the CTL response to two epitopes was performed as shown in Fig. 4 and Table IV. This analysis was done using allogeneic EBV-BCL that are partially matched with the effector cells at class I. As shown in Fig. 4, the presence of the HLA-A2 allele is both required and sufficient for recognition and lysis of target cells by the CTL line specific for HCV core 178-187 derived from patient C-3. Similar results are shown for the response for the HCV NS3 1406-1415 specific CTL response of subject C2 (Table IV, $A$ ). Since all of the peptides used in this study contained the HLA-A2.1 binding motif, rigorous HLA-restriction analysis such as this was not performed in all patients. Since the EBV-BCL target cell most frequently used in our study (JY) is HLA-A2, B7, and Cw7 positive, it is theoretically possible, that some of the CTL responses could be $\mathrm{B} 7$ or $\mathrm{Cw} 7$ restricted. We think that this is unlikely especially since the binding motif for $\mathrm{B} 7$ and $\mathrm{Cw} 7$ have been elucidated recently and they differ considerably from the A2.1 motif $(16,17)$.

Recognition of peptide-sensitized target cells: dose-response and specificity analysis. Increasing concentrations of HCV core 178-187 peptide were used to sensitize target cells for lysis by a peptide-specific CTL line derived from patient C2. As illustrated in Table IV $(B)$, optimal target cell sensitization occurred at a concentration of $1 \mu \mathrm{M}$. Importantly, the cell line did not recognize target cells sensitized with another HLAA2 binding peptide, HBVcore 18-27 (Table IV, C), confirming the specificity of the response for the inducing peptide.

Cell surface phenotype. Positively selected CD4 ${ }^{+}$and CD8 ${ }^{+}$ cells from an HCV core 178-187 specific CTL line from patient C-2 were tested for peptide-specific recognition and lysis of an HLA-A2 matched EBV-BCL. Cytotoxic activity was limited to the $\mathrm{CD8}^{+}$subpopulation (Table IV, $D$ ). The analysis was further extended to the clonal level and cytotoxic $T$ cell clones were derived from lines by cloning using limiting dilution. The 


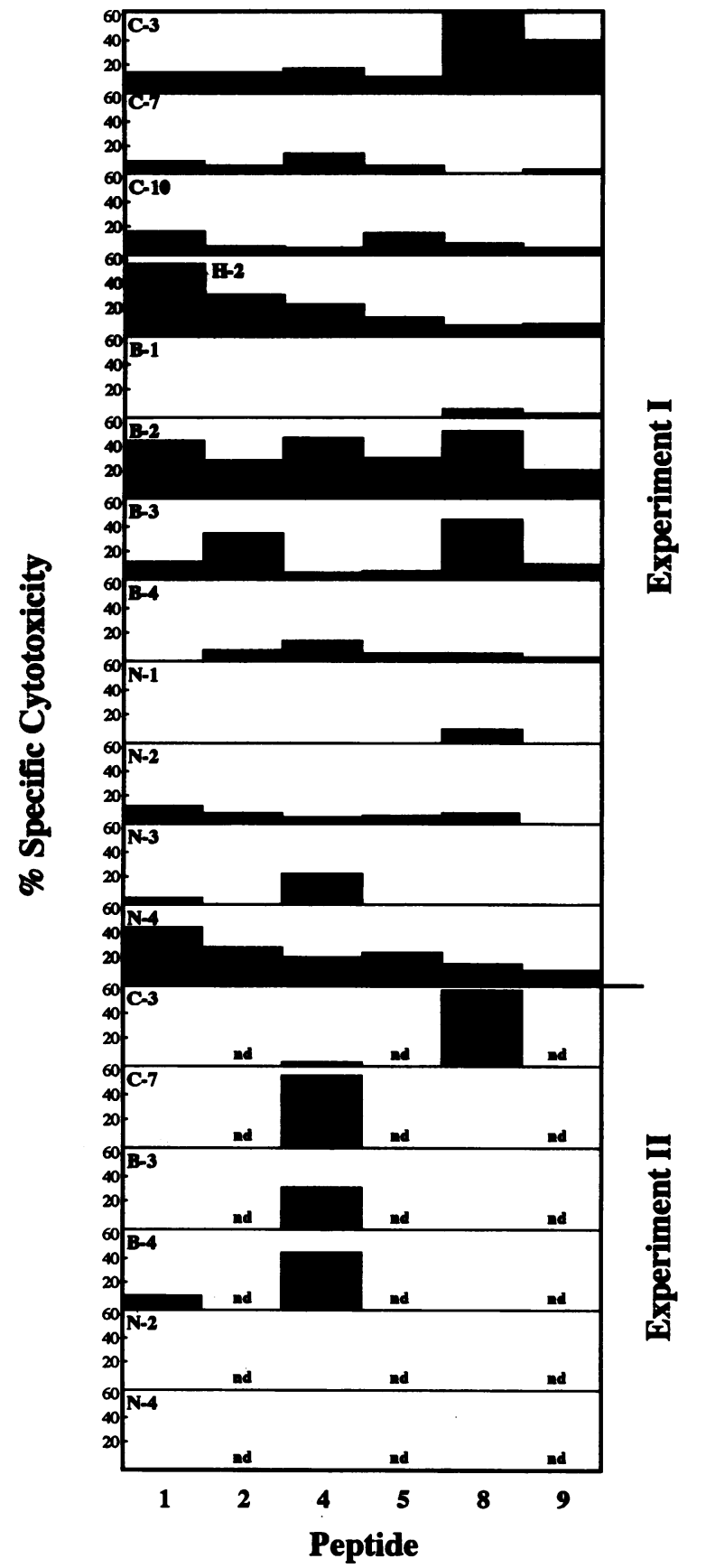

Figure 2. HCV specific CTL responses observed after 2 wk of in vitro expansion with HCV derived synthetic peptides: 1 -core 131-140; 2-core 178-187; 4-NS3 1406-1415; 5-NS4 1789-1797. Two peptides previously identified as HLA-A2 restricted CTL epitopes were used as controls: peptide 8-HBV core 18-27 (FLPSDFFPSV) and peptide 9-HBV env335-343 (WLSLLVPFV). The peptide specific cytotoxicity after 2 wk of culture at an effector to target cell ratio of 40/1 is shown. HLA-A2-matched JY EBV-BCL were used in all cases as target cells. Experiment I: PBMC isolated from four $\mathrm{HCV}$ infected patients (C-3, C-7, C-10 and $\mathrm{H}-2$ ), four patients with chronic hepatitis B (B-1 to B-4) and four seronegative donors ( $\mathrm{N}-1$ to $\mathrm{N}-4$ ) were similarly stimulated with HCV- and HBV-derived synthetic peptides. Experiment II: The PBMC of two HCV infected patients (C-3 and C-7), two patients with chronic hepatitis B (B-3 and B-4) and two seronegative donors ( $\mathrm{N}-2$ and $\mathrm{N}-4)$ were similarly stimulated with a smaller set of HCV and HBV derived synthetic peptides. Note: Patient C-3 was convalescent from acute hepatitis B at the time of this study. $n d$, not done.
Table III. HCV-specific CTL Lines

\begin{tabular}{|c|c|c|c|c|c|c|c|c|c|}
\hline \multirow[b]{2}{*}{ Subject } & \multirow[b]{2}{*}{ Peptide } & \multicolumn{2}{|c|}{$\begin{array}{c}2 \\
\text { weeks* }\end{array}$} & \multicolumn{2}{|c|}{3 weeks } & \multicolumn{2}{|c|}{4 weeks } & \multicolumn{2}{|c|}{5 weeks } \\
\hline & & $\mathrm{E} / \mathrm{T}$ & $\%^{*}$ & $E / T$ & $\%$ & $E / T$ & $\%$ & $E / T$ & $\%$ \\
\hline \multicolumn{10}{|c|}{ Experiment A } \\
\hline \multirow[t]{3}{*}{ C-2 } & Core $131-140$ & 52 & 61 & 25 & 50 & 72 & 76 & 30 & 76 \\
\hline & & & & & & 24 & 71 & 10 & 78 \\
\hline & & & & & & 8 & 43 & 3 & 51 \\
\hline \multirow[t]{3}{*}{$\mathrm{C}-2$} & Core $178-187$ & 36 & 28 & 25 & 37 & 64 & 81 & 18 & 69 \\
\hline & & & & & & 21 & 64 & 6 & 57 \\
\hline & & & & & & 7 & 33 & 2 & 24 \\
\hline \multirow[t]{3}{*}{ C-3 } & Core $178-187$ & 75 & 19 & 40 & 18 & 33 & 60 & 30 & 76 \\
\hline & & & & & & 11 & 37 & 10 & 52 \\
\hline & & & & & & 4 & 20 & 3 & 35 \\
\hline \multirow[t]{4}{*}{$\mathrm{C}-2$} & NS3 1406-1415 & 40 & 24 & 25 & 11 & 56 & 60 & 22 & 29 \\
\hline & & & & & & 19 & 30 & 7 & 14 \\
\hline & & & & & & 6 & 14 & 2 & 7 \\
\hline & NS5 2252-2260 & & & & & & & & \\
\hline \multirow[t]{5}{*}{$\mathrm{C}-2$} & $\operatorname{Exp} I^{\S}$ & 84 & 29 & nt & & & & & \\
\hline & NS5 2252-2260 & & & & & & & & \\
\hline & Exp II & 40 & 2 & 25 & 3 & 88 & 59 & 56 & 83 \\
\hline & & & & & & 29 & 29 & 19 & 49 \\
\hline & & & & & & 10 & 10 & 6 & 18 \\
\hline \multicolumn{10}{|c|}{ Experiment B } \\
\hline \multirow[t]{3}{*}{ C-3 } & Core $35-44$ & & nt & 30 & 45 & 32 & 77 & & nt \\
\hline & & & & 10 & 11 & 11 & 68 & & \\
\hline & & & & 3 & 1 & 4 & 36 & & \\
\hline \multirow[t]{2}{*}{$C-8$} & Core $35-44$ & & nt & 50 & 20 & 40 & 44 & & $\mathrm{nt}$ \\
\hline & & & & & & 13 & 16 & & \\
\hline \multirow[t]{2}{*}{$\mathrm{C}-8$} & NS3 1073-1081 & & nt & 50 & 17 & 48 & 31 & & nt \\
\hline & & & & & & 16 & 21 & & \\
\hline \multirow[t]{3}{*}{ C-9 } & NS3 1073-1081 & & nt & 50 & 26 & 40 & 48 & 84 & 62 \\
\hline & & & & & & 13 & 68 & 28 & 42 \\
\hline & & & & & & & & 9 & 19 \\
\hline \multicolumn{10}{|c|}{ Experiment $\mathrm{C}$} \\
\hline $\mathrm{C}-7$ & NS3 1406-1415 & 40 & 57 & 40 & 87 & 40 & 73 & 40 & 72 \\
\hline $\mathrm{N}-2$ & NS3 1406-1415 & 40 & 0 & 40 & 1 & 40 & 43 & 40 & 35 \\
\hline
\end{tabular}

* PBMC were stimulated with the HCV-derived synthetic peptides and restimulated weekly with autologous antigen presenting cells and peptide. Cultures were tested initially after $2 \mathrm{wk}$, then at weekly intervals for peptide specific CTL activity. ${ }^{\ddagger}$ Peptide specific cytotoxic activity at different numbers of effectors per target cell obtained in a 4-h ${ }^{51} \mathrm{Cr}$ release assay are shown. The PBMC for experiment I were collected 2 mo before experiment II. The patient did not receive any treatment during this period. $n t$, not tested.

resulting six clones (Table V) were isolated from three donors recognizing epitope core 131-140 and NS3 1406-1415. The clones from patients C- 2 and C- 5 were analyzed by flow cytometry and found to be $\mathrm{CD} 8^{+}$.

Recognition of endogenously synthesized antigen. Fig. 5 illustrates the ability of a CTL line from Subject C-5 (panel $A$ ) and a CD8 ${ }^{+}$clone (D55-3, panel $B$ ) derived from Subject C-3 (both specific for NS3 1406-1415) as well as a CTL line derived from subject C-9 specific for NS3 1073-1081 (panel $C$ ) to recognize endogenously synthesized antigen presented by recombinant $\mathrm{HCV}$ E2/NS2/NS3 vaccinia virus infected EBV$\mathrm{BCL}$ as well as exogenously added peptide. In addition to these results, a CTL line generated from subject C-8 specific for Core 


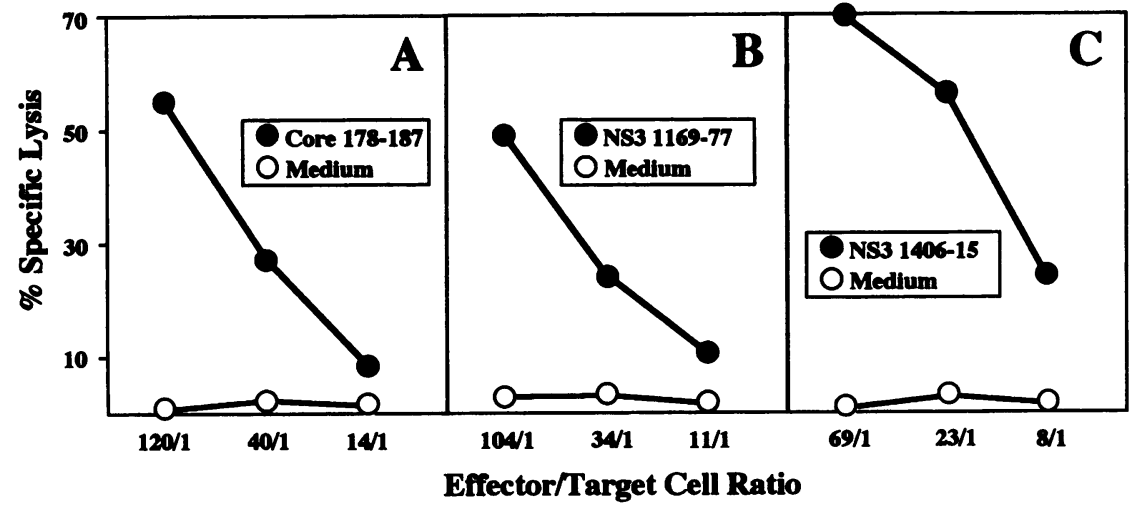

Figure 3. Cytotoxic activity of CTL lines specific for HCV peptides. CTL lines were obtained by weekly restimulation with peptides and autologous feeder cells. A representative example of CTL lines obtained from Subject C-3 is shown. The CTL lines are specific for HCV core 178$187(A)$, NS3 1169-1177 $(B)$ and NS3 1406$1415(C)$ and had been stimulated with peptide for four weeks prior to the CTL assay. Specific lysis of peptide pulsed (closed circles) and unpulsed (open circles) HLA-A2 matched JY EBV-BCL is shown.
35-44 and a CTL line derived from subject C-2 specific for Core 131-140 recognized endogenously synthesized antigen in target cells infected by recombinant $\mathrm{HCV}$ core/E1 vaccinia virus (Fig. 5, $D$ and $E$ ). These results demonstrate that CTL expanded in vitro with at least four of the HCV peptides identified as epitopes in this study are able to recognize and lyse virus infected target cells, suggesting that they may reflect the native structure of the naturally processed CTL epitopes produced by infected cells in vivo. It is noteworthy that we have consistently failed to demonstrate recognition of endogenous antigen by core 178-187 specific CTL lines or clones (data not shown). The NS3 1169-1177 specific effector cells have not been tested. We did not examine the capacity of the NS4 and NS5 specific CTL to recognize endogenously synthesized antigen because the necessary expression vectors were not available to us at the time this study was performed.

Analysis of peptide-specific CTL precursor frequency. To

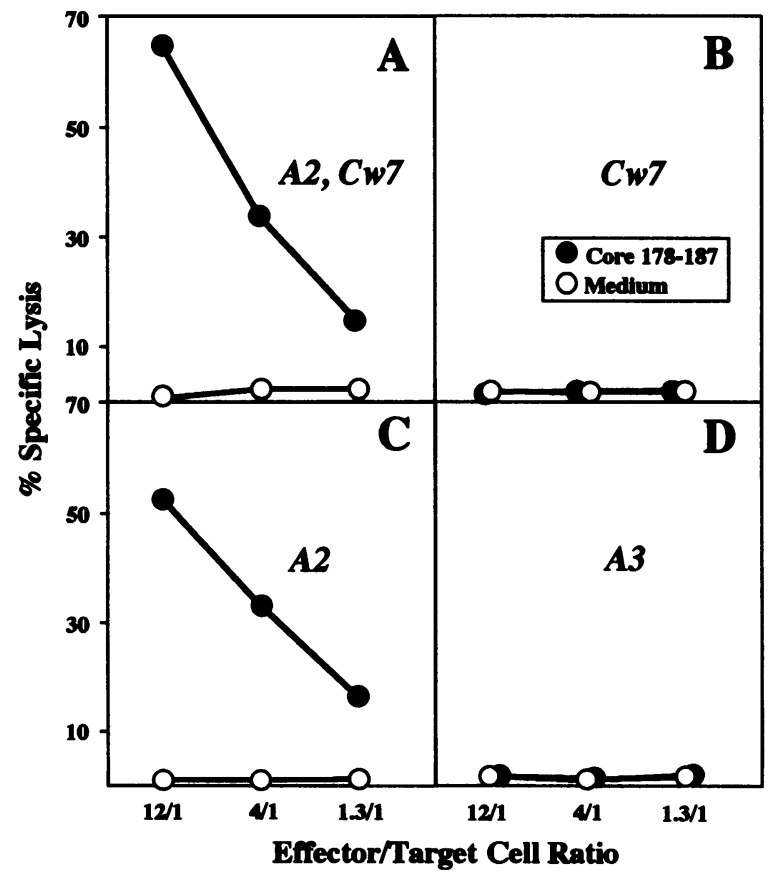

Figure 4. HLA class I restriction analysis. A CTL line specific for HCV core 178-187 was derived from subject C-3 (HLA-A2, A3, B44, Cw7) and tested for recognition and lysis of different peptide pulsed (closed circles) and unpulsed (open circles) EBV-BCL that match the effector cells for HLA-A2 and Cw7 $(A), \mathrm{Cw} 7(B), \mathrm{A}-2(C)$ and A-3 $(D)$. quantitate the number of peptide-specific CTL precursors in the peripheral blood we used a limiting dilution protocol and tested for CTL activity after three weeks of in vitro stimulation. Using this technique, the frequency of CTL precursors specific for an influenza matrix peptide M58-68 in three normal HLA-A2 ${ }^{+}$ donors was shown to be 2.7 CTL precursors per $10^{6}$ PBMC (95\% confidence interval 1.6-3.8), 2.5/106 PBMC (95\% confidence interval 1.1-3.8) and $1 / 10^{6}$ PBMC (95\% confidence interval 0.2-1.8), respectively. As illustrated in Fig. $6 \mathrm{~A}$, donor C-3, whose bulk cultures responded to NS3 1406-1415 (Figs. 1 and 2, Experiment I), displayed 10 to 100 -fold more NS3 1406-1415 specific CTL precursors than normal donor N-5. Similarly, as shown in $B$, donor C-7 displayed at least 100 -fold

Table IV. Characterization of the HCV-specific CTL Response of Subject $\mathrm{C}-2$

\begin{tabular}{|c|c|c|c|c|}
\hline \multirow[b]{2}{*}{ Effector cells* } & \multicolumn{3}{|c|}{ Target cells ${ }^{\ddagger}$} & \multirow{2}{*}{$\begin{array}{l}\text { Specififi } \\
\text { lysis }^{8}\end{array}$} \\
\hline & Shared HLA & Peptide & $\mu \mathrm{M}$ & \\
\hline & & & & $\%$ \\
\hline \multicolumn{5}{|l|}{ A } \\
\hline Unfractionated & $\mathrm{A} 2, \mathrm{~B} 7, \mathrm{Cw} 7$ & NS3 1406-1415 & 10 & 52 \\
\hline , & A2 & NS3 1406-1415 & 10 & 56 \\
\hline \multicolumn{5}{|l|}{ B } \\
\hline Unfractionated & A2, B7, Cw7 & Core $178-187$ & 0.001 & 0 \\
\hline , & " & Core $178-187$ & 0.01 & 12 \\
\hline ", & $"$ & Core $178-187$ & 0.1 & 45 \\
\hline , & , & Core $178-187$ & 1 & 93 \\
\hline , & , & Core $178-187$ & 10 & 72 \\
\hline \multicolumn{5}{|l|}{$\mathrm{C}$} \\
\hline Unfractionated & $\mathrm{A} 2, \mathrm{~B} 7, \mathrm{Cw} 7$ & Core $178-187$ & 10 & 60 \\
\hline , & , & HBV Core $18-27$ & 10 & 0 \\
\hline \multicolumn{5}{|c|}{ 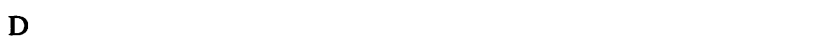 } \\
\hline $\mathrm{CD}^{+\|}$ & A2 & Core $178-187$ & 10 & 4 \\
\hline $\mathrm{CD}^{+}$ & A2 & Core $178-187$ & 10 & 72 \\
\hline
\end{tabular}

* PBMC derived from subject C-2 were stimulated with HCV-derived synthetic peptides and restimulated weekly with autologous antigen presenting cells and peptide as described. ${ }^{\ddagger}$ EBV-BCL were used as target cells matching effector cell class I allele expression as indicated. Target cell sensitization was performed overnight using the peptides at the concentrations shown. 8 Peptide specific cytotoxic activity using 25 effector cells per target cell obtained in a 4-h ${ }^{51} \mathrm{Cr}$-release assay. $11 \mathrm{CD} 4{ }^{+}$ and $\mathrm{CD}^{+}$cell populations were purified as described yielding $79 \%$ $\mathrm{CD}^{+}$cells and $87 \% \mathrm{CD}^{+}$cells respectively in the experiment shown. 
Table V. HCV-specific CTL Clones

\begin{tabular}{|c|c|c|c|c|c|c|}
\hline \multirow[b]{2}{*}{ Subject } & \multirow[b]{2}{*}{ Peptide } & \multirow[b]{2}{*}{ Clone* } & \multicolumn{2}{|c|}{ Cytotoxicity ${ }^{\ddagger}$} & \multicolumn{2}{|c|}{ Phenotype } \\
\hline & & & $\mathrm{E} / \mathrm{T}$ & $\%$ & $\mathrm{CD}^{+}$ & $\mathrm{CD}^{+}$ \\
\hline \multirow[t]{3}{*}{ C-2 } & Core $131-140$ & R15-115 & 3 & 67 & 1.4 & 83.6 \\
\hline & & & 1 & 42 & & \\
\hline & & & 0.3 & 27 & & \\
\hline \multirow[t]{3}{*}{ C-5 } & Core $131-140$ & H15-17 & 128 & 90 & 2.4 & 84.3 \\
\hline & & & 43 & 97 & & \\
\hline & & & 14 & 94 & & \\
\hline \multirow[t]{3}{*}{ C-5 } & Core $131-140$ & H15-26 & 68 & 84 & 3.9 & 99 \\
\hline & & & 22 & 89 & & \\
\hline & & & 7 & 76 & & \\
\hline \multirow[t]{3}{*}{ C-5 } & Core $131-140$ & H15-99 & 92 & 90 & 2.7 & 100 \\
\hline & & & 30 & 79 & & \\
\hline & & & 10 & 50 & & \\
\hline \multirow[t]{3}{*}{ C-3 } & NS3 $1406-1415$ & D55-3 & 0.9 & 44 & nd & nd \\
\hline & & & 0.3 & 16 & & \\
\hline & & & 0.1 & 5 & & \\
\hline \multirow[t]{3}{*}{ C-3 } & NS3 $1406-1415$ & D55-10 & 18 & 69 & nd & nd \\
\hline & & & 6 & 66 & & \\
\hline & & & 2 & 58 & & \\
\hline
\end{tabular}

* PBMC were stimulated with the indicated with the indicated HCVderived synthetic peptides and restimulated weekly with autologous antigen presenting cells and peptide. Clones were derived from highly cytotoxic CTL lines as described in the text. ${ }^{\ddagger}$ Peptide specific cytoxic activity at different numbers of effectors per target cell (JY; HLA-A2, B7, Cw7) obtained in a 4-h ${ }^{51} \mathrm{Cr}$-release assay are shown. ${ }^{8}$ Determined by flow cytometry as described in the text. nd, not done.

more NS3 1406-1415 specific CTL precursors than normal donor N-2. In bulk cultures (Fig. 2, Experiments I and II) donor C-7 responded to NS3 $1406-1415$ with $14 \%$ and $57 \%$ specific killing, while normal donor $\mathrm{N}-2$ did not respond (3\% and $0 \%$ lysis, respectively). The experiment in Fig. $6 C$ demonstrates that subject C-8 displayed at least 10-fold higher CTL precursor frequency to HCV core 131-140 than normal donor N-4 displayed to the HBV core 18-27 epitope. The low precursor frequency to the HBV epitope is in the same barely detectable range as the CTL precursor frequency to HCV NS3 14061415 in uninfected normal donors shown in the previous two experiments. Finally, as illustrated in $D$, the CTL precursor frequency to HBV core 18-27 was shown to be $\sim 1 / 10^{6}$ PBMC in chronic hepatitis B patient B-3 who responded to this peptide with $46 \%$ specific killing in bulk culture (Fig. 2, Experiment I). In contrast, the CTL precursor frequency to this peptide was at least 25-fold lower in normal donor N-6 who did not respond in bulk culture in the same experiments (Fig. 2, Experiment I).

To further distinguish between in vitro and in vivo priming, we compared the CTL precursor frequency to NS3 1406-1415 in unfractionated PBMC and CD45 RO-depleted PBMC from donor C-7 who previously responded to this peptide in bulk culture (Fig. 2, Experiment II) and in a previous LDA (Fig. 6 $B$ ) using an approach previously described by Merkenschlager et al. (29). FACS analysis of unseparated PBMC revealed $29.9 \% \mathrm{CD}^{2} 5 \mathrm{RO}^{+}$cells. Subsequent limiting dilution analysis revealed a sevenfold reduction of peptide-specific CTL precursors after removal of the $\mathrm{CD} 45 \mathrm{RO}^{+}$memory $\mathrm{T}$ cell population (Table VI) indicating that the majority of CTL precursors had been primed in vivo. Similarly, we analyzed the CTL precursor frequency to NS3 1406-1415 in unfractionated PBMC and CD45 RO-depleted PBMC from donor C-3 who previously responded to this peptide in bulk culture (Fig. 1) and in a previous LDA (Fig. $6 \mathrm{~A}$ ) and found a fourfold reduction of peptidespecific CTL precursors after removal of the CD45 $\mathrm{RO}^{+}$memory $\mathrm{T}$ cell population (Table VI).

\section{Discussion}

Our results can be summarized as follows: (a) CTL responses to nine $\mathrm{HCV}$ encoded peptides out of a selection of 130 peptides

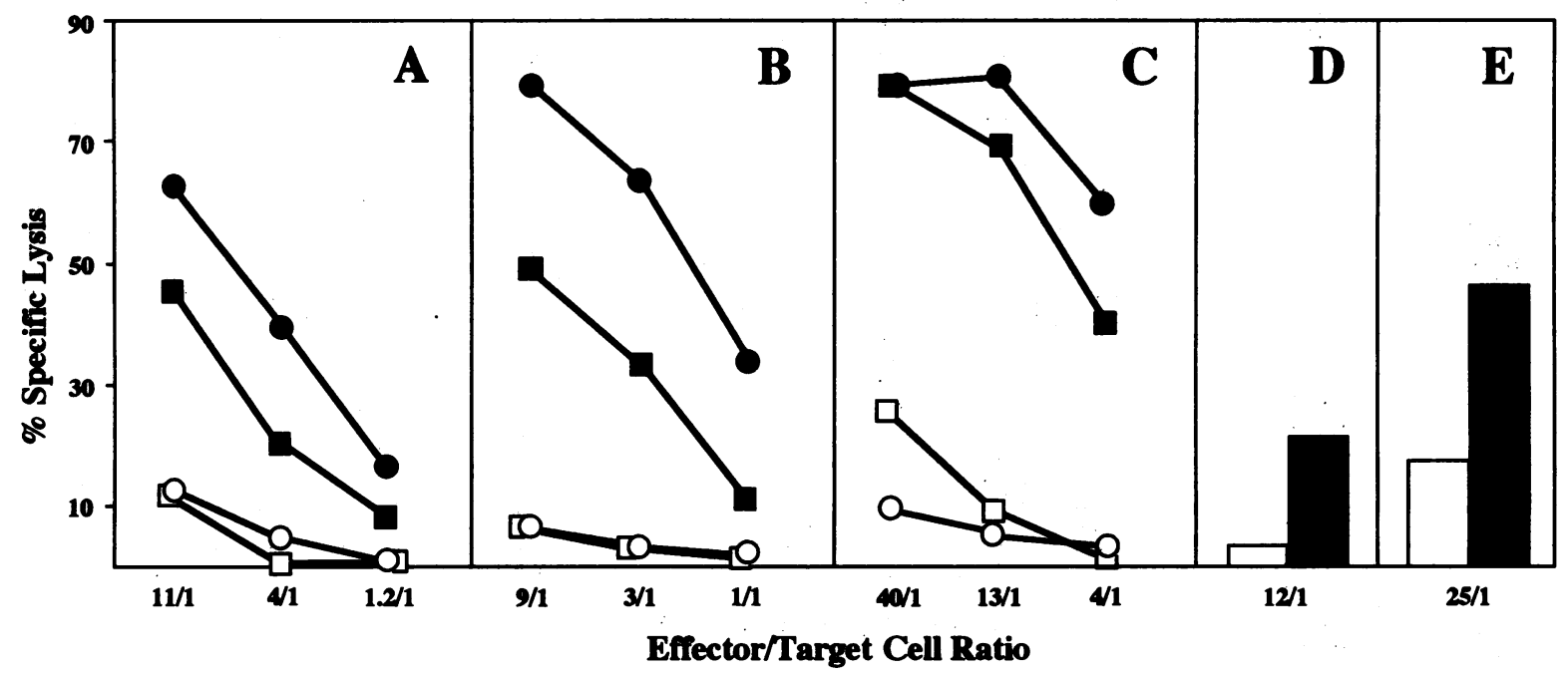

Figure 5. Recognition and lysis of target cells that synthesize viral antigen endogenously. Cytotoxicity analysis of CTL line from subject C-5 $(A)$, clone D55-3 derived from subject C-3 $(B)$, both specific for NS3 1406-1415, CTL line from subject C-9 specific for NS3 1073-1081 (C), CTL line from subject C-8 specific for HCV core 35-40 $(D)$ as well as a CTL line from subject C-2 specific for core 131-140 $(E)$. Target cells were HLA-A2-matched EBV-BCL that had been either pulsed with NS3 1406-1415 or NS3 1073-1081 peptide (closed circles) or medium alone (open circles), or that had been infected with a recombinant vaccinia virus construct containing the HCV aa sequence 364-1619 (A-C) and 1$339(D$ and $E)$, respectively (closed squares or bars) or with control vaccinia virus (open squares or bars). 


\section{CELLS PER CULTURE $\left(10^{5}\right)$}

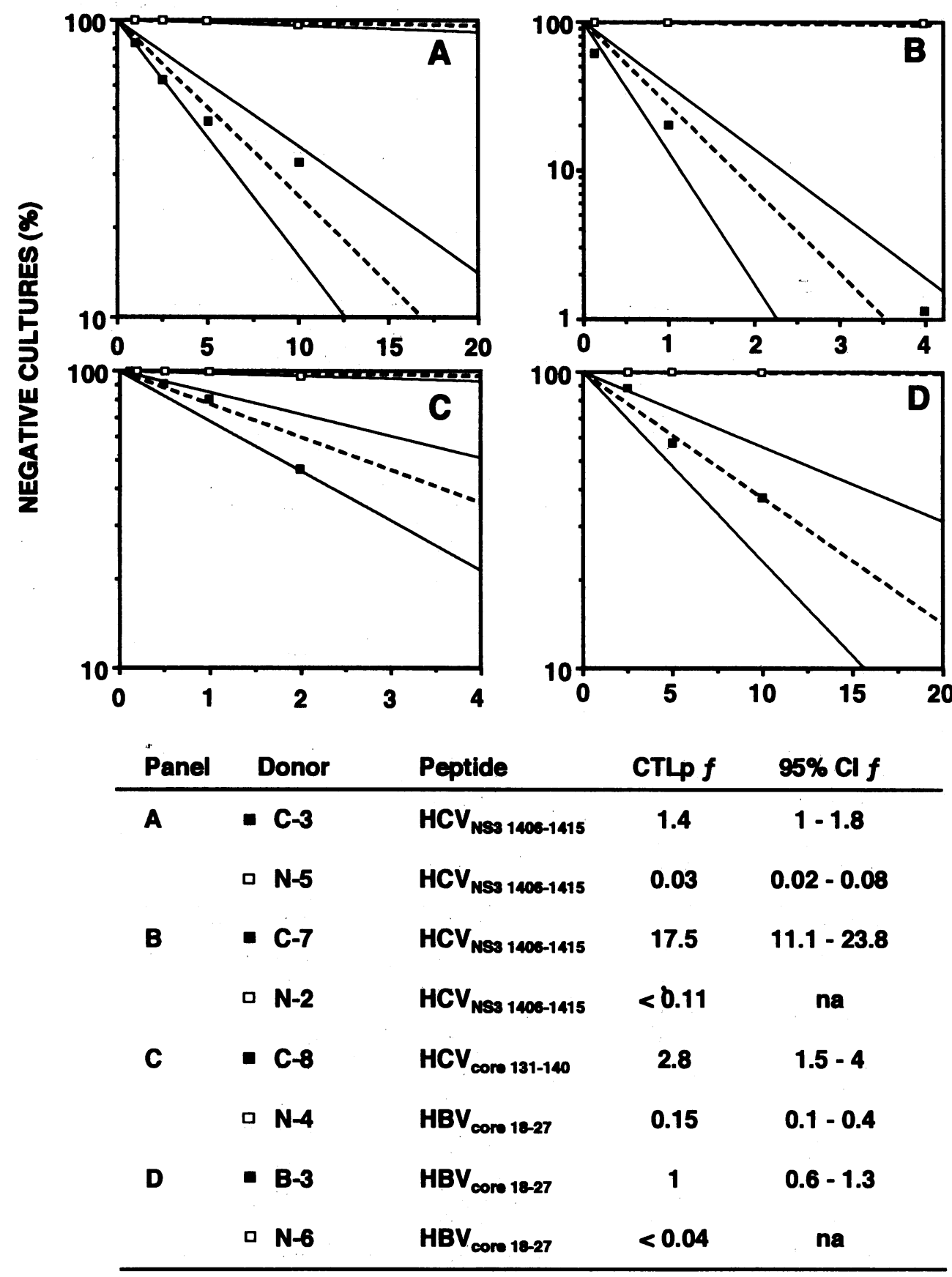

Figure 6. Analysis of the CTL precursor frequency of selected responses. Peptide specific CTL precusor frequencies were determined by limiting dilution analysis as described in four donor pairs consisting of an uninfected donor (N-5, N-4, N-2, N-6, open squares) and an $\mathrm{HCV}$-infected (C-3, C-8, C-7) or HBV-infected (B-3) subject. Each Panel displays the results of simultaneously performed experiments. The results are shown as semilogarithmic plot of responder cell input per well against the percentage of negative wells, and also in tabular form. CTLp $f=$ CTL precursor frequency expressed as number of peptide specific CTL precursor in $10^{6}$ PBMC. $95 \% \mathrm{CI}=95 \%$ confidence intervals. $n a$, no confidence intervals could be calculated. containing the HLA-A2.1 binding motif can be detected in the peripheral blood of patients chronically infected with HCV after 2 wk of in vitro stimulation. Three of the epitopes identified are derived from HCV core, three from NS3, two from NS4 and one from NS5. All are well conserved among HCV group I isolates. In accord with our findings, Shirai et al. (30) recently reported the identification of HLA-A2 restricted CTL specific for an epitope between residues 132-140 using PBMC from two patients with hepatitis $\mathrm{C}$, using a similar stimulation protocol. (b) Selected CTL effector cells were found to be CD8 ${ }^{+}$ and HLA-A2 restricted. (c) Effector cellis for four out of five epitopes tested were capable of recognizing endogenously syn- thesized antigen. $(d)$ Further analysis of the response to six of these epitopes revealed the presence of CTL precursors in HCV negative donors. (e) HCV infected subjects had 10 to 100 -fold higher CTL precursor frequencies to the three peptides analyzed by limiting dilution as compared to uninfected individuals and, in the two patients studied, most of the CTL precursors to NS3 1406-1415 proved to be CD45 RO positive indicating that they were "memory" CTL that had been primed in vivo. Finally, the CTL precursor frequencies for HCV derived peptides in $\mathrm{HCV}$ infected subjects are in the same range as those specific for influenza matrix peptide 58-68. Due to the cross-sectional design of this study however, and because of the responsiveness 
Table VI. Depletion of CD45 $\mathrm{RO}^{+}$Cells

\begin{tabular}{|c|c|c|c|c|}
\hline Subject & Peptide & $\mathrm{CD}^{2} 5 \mathrm{RO}^{+}(\%)^{*}$ & $\operatorname{CTLp} f^{\ddagger}$ & $95 \% \mathrm{Cl} f$ \\
\hline \multirow[t]{2}{*}{$\mathrm{C}-7$} & NS3 1406-1415 & 30 & 1.8 & $0.6-3$ \\
\hline & NS3 $1406-1415$ & 1.5 & $<0.23$ & $\mathrm{na}^{8}$ \\
\hline \multirow[t]{2}{*}{$\mathrm{C}-3$} & NS3 $1406-1415$ & 24 & 1.3 & $0.2-2.3$ \\
\hline & NS3 $1406-1415$ & 1 & 0.27 & $0.2-0.7$ \\
\hline
\end{tabular}

* Depletion of CD45 $\mathrm{RO}^{+}$PBMC by negative selection was performed as described and the percentage of $\mathrm{CD} 45 \mathrm{RO}^{+}$cells was determined by FACS. ${ }^{\ddagger}$ Peptide-specific CTL precursor frequencies were determined by limiting dilution analysis in CD45RO depleted and undepleted $\mathrm{PBMC}$ and the results given correspond to the number of peptide specific CTL precursor per $10^{6}$ PBMC. $95 \%$ CI $f, 95 \%$ confidence intervals.

${ }^{\S} n a$, no confidence intervals could be calculated.

of uninfected individuals (albeit at much lower levels) it is not possible to correlate the CTL response to the clinical or virological status of the patients at this time.

The identification of CTL epitopes is an important step to elucidate the role of CTL in the biology of human HCV infection, as suggested by a large body of experimental data obtained in diverse animal models. To draw valid conclusions however, the effector cells recovered from the blood must represent those present in the liver. Practical restrictions as to the availability of large samples of liver tissue in patients with active chronic liver disease make this a difficult task. Nonetheless, Koziel et al. (11) have isolated HCV E1 and E2(NS1)/NS2 specific class I restricted CTL clones from liver biopsies of patients in whom they were unable to detect the same CTL response in the peripheral blood. Importantly, however, these investigators have recently identified HLA-A2 restricted intrahepatic CTL specific for a peptide that contains the NS3 1073-1081 epitope that we report herein to be recognized by CTL derived from the PBMC of two HCV infected subjects (M. Koziel and B. Walker, personal communication) suggesting that the peripheral CTL response to this epitope probably reflect events occurring within the infected liver. Correlative studies using the sensitive quantitative approach described herein to follow epitope-specific CTL precursor frequency prospectively during the course of hepatitis $\mathrm{C}$ infection will help elucidate this important question.

Observations made during this study confirm and extend previous reports from this laboratory about the CTL response to HBV encoded epitopes in subjects with acute and chronic HBV infection (6-8). In those studies, HBV-specific CTL were readily identified in the peripheral blood of patients with acute hepatitis but were not detectable in patients with chronic hepatitis B or in uninfected normal subjects. In the current study, however, 2 of the 4 chronic HBV patients responded to one or both of the HBV peptides we used (Figure 2). This suggests that $\mathrm{HBV}$-specific CTL precursors are indeed present in these patients, albeit at low precursor frequencies $\left(1 / 10^{6} \mathrm{PBMC}\right)$ and that our original stimulation strategy failed to reveal them. This unexpected observation suggests that quantitative analysis of the CTL precursor frequency in patients with chronic HBV infection may yield insight into the immunological basis for variable and fluctuating disease severity, and, the spontaneous or interferon-induced clearance of HBV in chronic carriers. It is noteworthy that the HBV peptides did not induce a in vitro primary CTL response in any of the HBV uninfected donors in this study, similar to our previous observations.
The reason why we could detect $\mathrm{HBV}$-specific CTL responses in the two patients with chronic hepatitis B in the current study, while we didn't in our previous reports is not immediately evident. These patients were not included in any of our previous reports, so they may simply represent a previously undetected CTL responsive subset of patients with chronic HBV infection. In our previous studies, however, we used recombinant $\mathrm{HBcAg}$ as a source of $\mathrm{T}$ cell help, while in the current report tetanus toxoid was used. Conceivably, the current responses to the HBV peptides in chronically infected patients, and to the HCV peptides by uninfected controls, may be related to this difference, or it could be due to the longer in vitro stimulation period we employed before the first CTL assay. Obviously, additional studies will be required to clarify this interesting issue.

Two lines of evidence suggest that at least some of the CTL in the peripheral blood of $\mathrm{HCV}$ infected patients have been primed in vivo. First, we showed that HCV peptide-specific CTL precursors are present in higher numbers in $\mathrm{HCV}$ infected than in uninfected subjects. Second, we showed that, in the two cases tested, they belong to the CD45 $\mathrm{RO}^{+}$"memory" T cell subset. The HCV-specific CTL precursor frequencies we observed in the peripheral blood are in the range of $1 / 10^{5}$ to $10^{6}$ PBMC. Assuming that $80 \%$ of PBMC are lymphocytes, $60 \%$ of which are $\mathrm{T}$ cells, and that $20 \%$ the $\mathrm{T}$ cells are $\mathrm{CD}^{+}$, the CTL precursor frequencies translate to $1 / 30,000$ to $1 / 300,000$ $\mathrm{CD}^{+} \mathrm{T}$ cells. These relatively low frequencies are in part explained by the fact that our experimental system focuses on single epitopes restricted by single restriction elements. Importantly, comparable precursor frequencies were observed for an HLA-A2 restricted epitope in the influenza matrix protein when PBMC from presumably previously infected normal blood donors were studied. Several groups have applied limiting dilution analysis to quantitate HIV-specific CTL precursors in the peripheral blood in infected donors. In one study the gag p24 peptide-specific CTLp frequency was between $120-280 / 10^{6}$ PBMC in asymptomatic HIV-1 infected hemophiliacs (31). In lymphoid tissue on the other hand, another group reported a frequency of $1 / 10^{5}$ to $1 / 10^{6} \mathrm{CTL}$ specific for a nef peptide 182-206 restricted by HLA-A1 and B8 (32). These differences are in accord with the finding that the cytotoxic response to HIV is particularly vigorous, allowing the detection of effector cells directly from the blood without prior in vitro expansion (33).

Since we observed the primary in vitro induction of CTL to all four of the HCV CTL epitopes we tested in normal individuals (albeit at much lower precursor frequency), and since additional experiments with HCV core 35-44 and NS3 10731081 also revealed the presence of CTL precursors in uninfected subjects (Cerny et al. manuscript in preparation), the pathogenetic significance of the current observations is not immediately evident. Our findings are clearly relevant, however, for vaccine development and for adoptive immunotherapy. Epitopes from conserved regions of the virus that are generated by the intracellular processing of endogenously synthesized antigen are particularly good candidates for vaccine development. This information, combined with the prevalence and degree of conservation of a given epitope (Table II), can be used in the design of a peptide-based $\mathrm{HCV}$ vaccine. Additionally, the in vitro generation of large numbers of biologically active, virus-specific effector cells is a prerequisite for adoptive immunotherapy. The techniques described in this report permit detection and expansion of naive peripheral blood CTL precursors to candidate viral 
peptides. The use of this simple culture system could make the large scale ex vivo expansion of specific CTL possible.

\section{Acknowledgments}

We thank Conrad Hauser for helpful discussions and Linda Wilkes and Kendis Cox for their assistance in recruiting the patients and the processing of the blood samples, and Bonnie Weier for assistance with manuscript preparation. We also thank Drs. Qui Lim Choo and Robert Ralston for their work on vaccinia constructs. This is manuscript number 8118-MEM from the Scripps Research Institute.

This work was supported by grant RO1 AI-20001 and RR-00833 from the National Institutes of Health. A. Cerny was supported by a fellowship of the Schweizerische Stiftung für Medizinisch Biologische Stipendien, SNF grant 32-37291.93 and the Central Laboratory Blood Transfusion Service, M. Brothers was supported by a training grant, AR-07144, from the National Institutes of Health.

\section{References}

1. Choo, Q. L., G. Kuo, A. J. Weiner, L. R. Overby, D. W. Bradley, and M Houghton. 1989. Isolation of a cDNA clone derived from a blood-borne non-A, non-B viral hepatitis genome. Science (Wash. DC). 244:359-362.

2. Houghton, M., A. Weiner, J. Han, G. Kuo, and Q. L. Choo. 1990. Molecular biology of the hepatitis $\mathrm{C}$ viruses: implications for diagnosis, development and control of viral disease. Hepatology. 14:381-388.

3. Kuo, G., Q. L. Choo, H. J. Alter, G. I. Gitnick, A. G. Redeker, R. H Purcell, T. Miyamura, J. L. Dienstag, M. J. Alter, C. E. Syevens, G. E. Tegtmeier F. Bonino, M. Colombo, W. S. Lee, C. Kuo, K. Berger, J. R. Shuster, L. R. Overby, D. W. Bradley, and M. H. Houghton. 1989. An assay for circulating antibodies to a major etiologic virus of human non-A, non-B hepatitis. Science (Wash. DC). 244:362-364.

4. Mosmann, T. R., H. Cherwinski, M. W. Bond, M. A. Giedlin, and R. L. Coffman. 1986. Two types of murine helper T cell clone I. Definition according to profiles of lymphokine activities and secreted proteins. J. Immunol. 136:23482357.

5. Zinkernagel, R. M., and P. C. Doherty. 1979. MHC-restricted cytotoxic T cells: studies on the biological role of polymorphic major transplantation antigens determining T-cell restriction-specificity. Adv. Immunol. 19:51-74.

6. Bertoletti, A., C. Ferrari, F. Fiaccadori, A. Penna, R. Margolskee, H-J. Schlicht, P. Fowler, S. Guilhot, and F. V. Chisari. 1991. HLA class I-restricted human cytotoxic $\mathrm{T}$ cells recognize endogenously synthesized hepatitis $\mathrm{B}$ virus nucleocapsid antigen. Proc. Natl. Acad. Sci. USA. 88:10445-10449.

7. Penna, A., F. V. Chisari, A. Bertoletti, G. Missale, P. Fowler, T. Giuberti, F. Fiaccadori, and C. Ferrari. 1991. Cytotoxic T lymphocytes recognize an HLAA2-restricted epitope within the hepatitis B virus nucleocapsid antigen. $J$. Exp. Med. 174:1565-1570.

8. Nayersina, R., P. Fowler, S. Guilhot, G. Missale, A. Cerny, H-J. Schlicht, A. Vitiello, R. Chesnut, J. L. Person, A. G. Redecker, and F. V. Chisari. 1993 HLA A2 restricted cytotoxic lymphocyte responses to multiple hepatitis B surface antigen epitopes during hepatitis B virus infection. J. Immunol. 150:4659-4671.

9. Barnaba, V., A. Franco, A. Alberti, C. Balsano, R. Benvenuto, and F. Balsano. 1989. Recognition of hepatitis B envelope proteins by liver-infiltrating $\mathrm{T}$ lymphocytes in chronic HBV infection. J. Immunol. 143:2650-2655.

10. Zinkernagel, R. M., E. Haenseler, T. Leist, A. Cerny, H. Hengartner, and A. Althage. 1986. T cell-mediated hepatitis in mice infected with lymphocytic choriomeningitis virus: liver cell destruction by $\mathbf{H}-2$ class I restricted virus specific $\mathrm{T}$ cells as a physiological correlate of the $51 \mathrm{Cr}$-release assay? J. Exp. Med. 164:1075-1092.

11. Koziel, M. J., D. Dudley, J. T. Wong, J. Dienstag, M. Houghton, R. Ralston, and B. D. Walker. 1992. Intrahepatic cytotoxic T lymphocytes specific for hepatitis C virus in persons with chronic hepatitis. J. Immunol. 149:33393344 .

12. Matsumura, M., D. H. Fremont, P. A. Peterson, and I. A. Wilson. 1992 Emerging principles for the recognition of peptide antigens by MHC class molecules. Science (Wash. DC). 257:927-930.

13. Falk, K., O. Roetzschke, S. Stevanovic, G. Jung, and H-G. Rammensee.
1991. Allele-specific motifs revealed by sequencing of self-peptides eluted from MHC molecules. Nature (Lond.). 351:290-296.

14. Guo, H-C., T. S. Jardetzky, T. P. J. Garrett, W. S. Lane, J. L. Strominger, and D. C. Wiley. 1992. Different length peptides bind to HLA-Aw68 similarly at their ends but bulge out in the middle. Nature (Lond.). 360:364-366.

15. Jardetzky, T. S., W. S. Lane, R. A. Robinson, D. R. Madden, and D. C. Wiley. 1991. Identification of self peptides bound to purified HLA-B27. Nature (Lond.). 353:326-329.

16. Huczko, E. L., W. M. Bodnar, D. Benjamin, K. Sakaguchi, N. Z. Zhu, J. Shabanowitz, R. A. Henderson, E. Appella, D. F. Hunt, and V. H. Engelhard. 1993. Characteristics of endogenous peptides eluted from the class I MHC molecule HLA-B7 determined by mass spectrometry and computer modeling. J. Immunol. 151:2572-2587.

17. Falk, K., O. Rötzschke, B. Grahovac, D. Schendel, S. Stevanovic, V. Gnau, G. Jung, J. L. Strominger, and H. G. Rammensee. 1993. Allele-specific peptide ligand motifs of HLA-C molecules. Proc. Natl. Acad. Sci. USA. 90:1200512009.

18. Missale, G., A. Redeker, J. Person, P. Fowler, S. Guilhot, H.-J. Schlicht, C. Ferrari, and F. V. Chisari. 1993. HLA-A31 and Aw68 restricted cytotoxic T cell responses to a single hepatitis B virus nucleocapsid epitope during acute viral hepatitis. J. Exp. Med. 177:751-762.

19. Guilhot, S., P. Fowler, G. Portillo, R. F. Margolskee, C. Ferrari, A. Bertoletti, and F. V. Chisari. 1992. Hepatitis B virus (HBV)-specific cytotoxic T cell response in humans: Production of target cells by stable expression of HBVencoded proteins in immortalized human B cell lines. J. Virol. 66:2670-2678.

20. Choo, Q. L., K. H. Richman, J. H. Han, K. Berger, C. Lee, C. Dong, C. Gallegos, D. Coit, A. Medina-Selby, P. J. Barr, A. J. Weiner, D. W. Bradley, G. Kuo, and M. Houghton. 1991. Genetic organization and deversity of the hepatitis C virus. Proc. Natl. Acad. Sci USA. 88:2451-2455.

21. Okamoto, H., Y. Sugiyama, S. Okada, K. Kurai, Y. Akahane, Y. Sugai, T. Tanaka, K. Sato, F. Tsuda, Y. Miyakawa and M. Mayumi. 1992. Typing hepatitis $\mathrm{C}$ virus by polymerase chain reaction with type-specific primers: applications to clinical surveys and tracing infectious sources. J. Gen. Virol. 73:673679 .

22. Simmonds, P. 1994. Variability of the hepatitis C virus genome. In Hepatitis C Virus. H. W. Reesink, editor. Karger, Basel. 12-35.

23. Bukh, J., R. H. Purcell, and R. H. Miller. 1992. Importance of primer selection for the detection of hepatitis C virus RNA with the polymerase chain reaction assay. Proc. Natl. Acad. Sci. USA. 89:187-191.

24. Cheng, K-C., G. L. Smith, and B. Moss. 1986. Hepatitis B virus large surface protein is not secreted but is immunogenic when selectively expressed by recombinant vaccinia virus. J. Virol. 60:337-344.

25. Spaete, R., A. D'Anna, M. Rugroden, Q.-L. Choo, K. Berger, K. Crawford, C. Kuo, S. Leng, C. Lee, R. Ralston, K. Thudium, J. Tung, G. Kuo, and M Houghton. 1992. Characterization of the hepatitis C virus E2/NS1 gene product expressed in mammalian cells. Virology. 188:819-830.

26. Chakrabati, S., K. Brechling, and B. Moss. 1985. Vaccinia virus expression vector: coexpression of the $\beta$-galactosidase provides visual screening of recombinant virus plaques. Mol. Cell Biol. 5:3403-3409.

27. Gotch, F., J. Rothbard, K. Howland, A. Townsend, and A. McMichael. 1987. Cytotoxic $\mathrm{T}$ lymphocytes recognize a fragment of influenza virus matrix protein in association with HLA-A2. Nature (Lond.). 326:881-882.

28. Taswell, C. 1986. Limiting dilution assays for the separation, characterisation and quantitation of biologically active particles and their clonal progeny. In Cell Separation: Selected Methods and Applications. T. G. Pretlow and T. P. Pretlow, editors. Academic Press, New York.

29. Merkenschlager, M. L. Terry, R. Edwards and P. C. L. Beverley, 1988. Limiting dilution analysis of proliferative responses in human lymphocyte populations defined by the monoclonal antibody UCHL1: implications for differential CD45 expression in T cell memory formation. Eur. J. Immunol. 18:1653-1661.

30. Shirai, M., T. Akatsuka, C. D. Pendleton, R. Houghten, C. Wychowski, K. Mihalik, S. Feinstone, and J. A. Berzofsky. 1992. Induction of cytotoxic T cells to a cross-reactive epitope in the hepatitis $\mathrm{C}$ virus nonstructural RNA polymerase-like protein. J. Virol. 66:4098-4106.

31. Gotch, F. M., D. F. Nixon, N. Alp, A. J. McMichael, and L. K. Borysiewicz. 1990. High frequency of memory and effector gag specific cytotoxic $\mathrm{T}$ lymphocytes in HIV seropositive individuals. Int. Immunol. 2:707-712.

32. Hadida, F., A. Parrot, M.-P. Kieny, B. Sadat-Sowti, C. Mayaud, P. Debre, and B. Autran. 1992. Carboxy-terminal and central regions of human immunodeficiency virus-1 NEF recognized by cytotoxic $\mathrm{T}$ lymphocytes from lymphoid organs. J. Clin. Invest. 89:53-60.

33. Plata, F., B. Autran, L. P. Martins, S. Wain-Hobson, M. Raphael, C Maynaud, M. Denis, J. M. Guillon, and P. Debre. 1987. AIDS virus specific cytotoxic T lymphocytes in lung disorders. Nature (Lond.). 328:348-351. 